\title{
A VALLÁS KOGNITÍV ELMÉLETEI: ÁTTEKINTÉS
}

\author{
SZABÓ LAJOS \\ PhD-hallgató, Pécsi Tudományegyetem, Pszichológia Doktori Iskola \\ E-mail: szabo.lajos04@gmail.com
}

Beérkezett: 2018. január 26. - Elfogadva: 2018. július 16.

A tanulmány célja bemutatni és értékelni azt az új tudományterületet, amely a „vallás kognitív tudománya" (Cognitive Science of Religion) néven vált ismertté. Az irányzat képviselöi a kognitív tudománynak és kognitív pszichológiának az elméleteit és módszereit alkalmazzák a vallás újszerú magyarázata során. Az itt következố tanulmány errôl az irányzatról nyújt átfogó értékelést, amit három szempont is indokolhat. Egyrészt, ez a terület az utóbbi idôszakban jelentốs fejlôdésen ment át - mára pedig az önálló tudományos diszciplinává válás küszöbére is eljutott. Másrészt, a fentiek ellenére az irányzat Magyarországon viszonylag kevéssé ismert, ezért mind a kognitív tudományok, mind a vallástudományok hazai képviselóinek szempontjából elốrevivố lehet egy ilyen általános áttekintés. Harmadrészt, fontos rámutatni arra, hogy az új irányzat sikeresen alkalmazott egy kognitív és naturalista megközelitést a vallásra - vagyis egy olyan jelenségre, mely korábban leginkább a humán-és társadalomtudományok illetékességi területéhez tartozott.

Kulcsszavak: kognitív tudományok; vallástudományok; a vallás kognitív alapjai; kogníció és kultúra; ágencia, elmeteória

\section{BEVEZETÉS: A VALLÁS KOGNITÍV MAGYARÁZATAINAK MEGJELENÉSE}

A kognitív tudomány tárgyát, az egyik legelterjedtebb meghatározás szerint, a megismerési folyamatoknak a multidiszciplináris irányultságú vizsgálata jelenti. Vagyis a kognitív megközelítés több különbözô tudományterületen is megjelent (kognitív nyelvészet, pszichológia, idegtudomány, etológia, antropológia), azonban ennek hátterében minden területen néhány közös alapgondolat áll. Így például az a felfogás, hogy a megismeró rendszerek elsôdleges feladata a saját környezetüknek a modellálása, amelynek során különbözô típusú reprezentációkat hoznak létre és használnak fel (Pléh, 2013; Sperber, 2001). 
A kognitív megközelítés elôtérbe kerülésének az egyik fontos következménye, hogy korábban függetlennek tartott tudományterületek is új szempontok mentén kapcsolódhattak egymáshoz. Az 1990-es évektôl e folyamat részeként egy új kérdésfeltevés került elôtérbe, jelentôs részben Dan Sperber (2001) hatására is. Mégpedig az, hogy a különbözô kultúrákon belül használatos reprezentációk (hiedelmek, képzetek, szimbólumok, rítusok) tulajdonságait és elterjedését a kogníció vagy a kultúra határozza-e meg elsôdlegesen. Az e kérdésre adott egyik legkidolgozottabb választ egy szintén az 1990-es években kialakuló, új irányzat fogalmazta meg, amely a „kognitív vallástudomány" (cognitive science of religion) elnevezést kapta (lásd Barrett, 2000; Lawson, 2001). Ez az irányzat a vallás témakörének a magyarázatát kapcsolja össze az emberi kogníció észlelési és következtetési folyamataira vonatkozó elméletekkel (Boyer, 2001; Atran, 2002; Barrett, 2004; Pyysiäinen, 2009).

A jelen írás tárgya tehát ennek az új területnek a bemutatása és értékelése lesz. Ennek elsô lépéseként érdemes kitérni az angol nyelvú elnevezés magyar nyelvre való fordításának kérdéseire. ${ }^{1}$ Korábban leginkább a fent is említett „kognitív vallástudomány" névváltozat vált használatossá (például: Biró, 2011; Szabó, 2016). Ez értelmét tekintve pontos fordítás, mivel a magyar tudományos terminológiában (és az angolban is) a „vallástudomány” (science of religion) mint általánosító kifejezés magába foglalja számos eltérô tudományágnak a vallással foglalkozó részterületeit. Más oldalról azonban tartalmilag e fordítás erôsen megkérdôjelezhetô. Az eredeti elnevezésben ugyanis nemcsak a „vallástudomány”, de a „kognitív tudomány” szóösszetétel is benne rejlik, ezért az angol kifejezés tartalma kétféleképpen is visszaadható (1. ábra).

A bemutatott kétféle fordítási lehetôség közül az 1. változat mellett szólhat, hogy korábban részben már meghonosodott, és megfelel a tudományterületekre vonatkozó „nevezéktan” hazai szabályainak is. Másrészt azonban fontos rámutatni, hogy a „kognitív vallástudomány" kifejezés több szempontból is pontatlan. Ugyanis az irányzat sem történetét, sem pedig elméleti és módszertani kereteit tekintve nem kötôdik a vallástudományokhoz - sốt inkább módszertani kritikával illeti azokat. Ehelyett a kognitív tudományokhoz, illetve a kognitív és evolúciós pszichológiához kapcsolódva alakult ki, azok kérdésfeltevéseit a vallásra alkalmazva (Barrett, 2000; Boyer és Bergstrom, 2008; Visala, 2011). Ezért a tartalmilag pontosabb fordítást a szórendjében szokatlanabb 2. változat jelentheti: „a vallás kognitív tudománya”. Az elnevezést megalkotó kutatók (Barrett, 2017; Lawson, 2001) szándéka szintén az volt, hogy az új név visszaadja a kognitív tudományoknak a vallás témájával való összekapcsolását. Az elnevezés

Az irányzat recepciójára Magyarországon úgy a vallástudományok, mint a kognitív tudományok területén is csak korlátozottan került sor. Ugyanakkor érdemes megemlíteni itt két magyar kutató nevét, akik kognitív megközelítésnek a vallástörténet területére való kiterjesztésének résztvevối. A Finnországban dolgozó Chachesz István (jelenleg University of Troms $\emptyset$, Norvégia) vallástörténészként a korai kereszténység vallásos képzeteire alkalmazta a kognitív megközelítést. Biró Tamás (Eötvös Lóránd Tudományegyetem) hebraistaként pedig az ószövetségi zsidó vallást vizsgálta ebben a megközelítésben. 


\section{Cognitive $+\underline{\text { Science of Religion }}=$ Kognitív $+\underline{\text { Vallástudomány }}$}

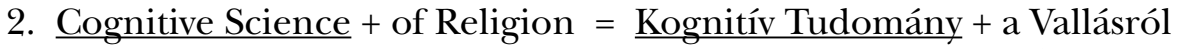 (- vagy: A Vallás + Kognitív Tudománya)}

1. ábra. „Cognitive Scinece of Religion” (CSR): Az angol nyelvú kifejezés fordításának két lehetséges változata, annak megfelelően, hogy melyik szóösszetételt emeljük ki (az ábrán aláhúzással jelölve) meghatározó jelentôségúként

Megjegyzés: Az eddigi magyar nyelvú említések során az 1. változat jelent meg, aminek egyik oka, hogy az irányzat megjelenésére idehaza inkább a vallástudományok képviselôii reflektáltak. Viszont a 2. változat tartalmilag pontosabbnak tekinthetô, mivel kifejezi az irányzatnak a kognitív tudományokkal fennálló szoros kapcsolatát (lásd a szövegben).

fordításának e problematikussága miatt, ${ }^{2}$ e tanulmányban az eredeti „, cognitive science of religion" kifejezés nemzetközileg elterjedt, betûszavas rövidítését (CSR) alkalmazom (illetve néhány esetben, de mindig idézôjelesen, használom a „kognitív vallástudomány” változatot is).

Az elnevezés fordításának kérdésköre után térjünk rá röviden az irányzat kialakulásának folyamatára. A fó motivációt kezdetben a vallás társadalomtudományokban - azon belül is fóleg a szociális és kulturális antropológiában - érvényes magyarázatainak a felváltása jelentette (Guthrie, 1993; Boyer, 2001). Az antropológia volt ugyanis az a tudományág, melynek folyamatosan a meghatározó tárgya, és a két nagy, központi témájának az egyike maradt a vallás (a másik ilyen nagy témát a rokonsági rendszerek jelentették). Mindennek megfelelően nyilván nem véletlen, hogy az irányzatot leginkább meghatározó szerzôk közül többen is antropológusként fordultak a vallás kognitív magyarázata felé. E téren a következô öt kutató korai munkáit érdemes kiemelni: Steve Guthrie (1993), Dan Sperber (2001), Pascal Boyer (1993, 2001), Scott Atran (2001) és Harvey Whitehouse (2000). Az ó esetükben az összekötô kapocsnak az tekinthetô, hogy a vallás kognitív elméleteit dolgozták ki az 1980-as, 1990-es évektôl. (Guthrie és Sperber késôbb nem kapcsolódott be közvetlenül a CSR mozgalmába, viszont mindketten alapvetô hatással voltak az irányzat kibontakozására.)

A felsorolt antropológus szerzókön kívül, a korai idôszakból fontos még megemlíteni az E. T. Lawson és R. N. McCauley szerzôpárost (elôbbi vallástörténész, az utóbbi filozófus), akik a rituális cselekvés kognitív elméletét dolgozták ki (Lawson és McCauley, 1990). A fejlôdéspszichológus J. L. Barrett pedig több, Guthrie és Boyer által felvetett témát továbbfejlesztett, és kísérleti vizsgálatokkal is összekapcsolta azokat

2 Mindez indokolttá teszi az itt említett 1. változat, a „kognitív vallástudomány” kifejezés helyettesítésére alkalmas, további magyar nyelvú elnevezés használatának a szakmai mérlegelését is. Az egyik lehetséges megoldás a kifejezésnek az idézőjelekkel történô használata (ahogy ebben a tanulmányban is teszem). Egy másik lehetôség pedig „a vallás kognitív tudománya” változat használata, akár idézôjellel, akár nélküle. A kérdés véleményem szerint további szakmai megvitatást érdemelne a vallástudományok, illetve a kognitív tudományok képviselôi részérôl is. 
(Barrett, 2004, 2011). Mindezek a kognitív valláselméletek kezdetben, az 1990-es évek folyamán még nem alkottak egységes irányzatot. Viszont az egy irányba mutató kérdésfeltevések felismerése rövid idôn belül elvezetett az új kutatási terület önállóságának a kihirdetéséhez (lásd Barrett 2000; Lawson, 2001).

Napjainkra az irányzat tulajdonképpen egy nagyrészt önálló és dinamikusan fejlôdô tudományterületnek (diszciplinának) tekinthetô (McCorkle és Xygalatas, 2013; McCauley, 2017). Ennek megfelelốen, több olyan tendencia is lezajlott, amely az irányzat intézményesülésének irányába mutat (McCorkle és Xygalatas, 2013; Pyysiäinen, 2012). Így 2006-ban megalakult a CSR képviselôinek nemzetközi szövetsége (International Association for the Cognitive Science of Religion, röviden IACSR), melynek hivatalos folyóirata a Journal for the Cognitive Science of Religion. Néhány európai és észak-amerikai egyetemen már sor került az irányzathoz kötôdő, új kutatási centrumok létrehozására; ezzel párhuzamosan pedig az irányzatnak szentelt tematikus folyóiratszámok, konferenciák és szerkesztett monográfiák száma is exponenciálisan növekedett (Xygalatas és McKay, 2013).

A legfontosabb eredmény mindazonáltal az, hogy az irányzat a vallásnak egy olyan új magyarázatát alakította ki, amely a kognitív és evolúciós pszichológia elméleti kereteinek a következetes alkalmazásán alapul - ezt a modellt mutatom majd be a 2. fejezetben.

\section{AZ IRÁNYZAT ELMÉLETI KERETEI}

A 2000-es évektôl kezdve a „kognitív vallástudomány” területe annyira szerteágazóvá vált, hogy valamennyi aspektusa aligha ismertethetô egy ilyen rövid tanulmány keretein belül (fontosabb összegzések: Barrett, 2004; Tremlin, 2006; Pyysiäinen, 2009; kritikai értékelése: Visala, 2011). Az irányzat központi célját a vallásos képzeteknek a pontosan meghatározható kognitív folyamatokra való visszavezetése (oksági magyarázata) jelentette. E célkitúzés eredménye az, hogy mára a vallás jól kidolgozott és számos részjelenségre kiterjeszthetô, „standard kognitív modelljéról” beszélhetünk (Boyer és Bergstrom, 2008). A részletekbe menô bemutatás helyett itt az irányzat egészét meghatározó tézisek (alapfeltevések) közül négyet emelek ki, a következôkben ezeket tekintem át öt alfejezetben.

\subsection{Az elme moduláris modellje alkalmazható a valláshoz sorolható jelenségek magyarázatára}

Az elme modularitásának tézise, amely a kognitív tudomány és az evolúciós pszichológia területein belül is széles körben elfogadott (Tooby és Cosmides, 1992; Pinker, 2002), az új irányzat képviselôinek a kiindulási alapját is jelentette (Atran 2002; Boyer 2001). E modell szerint az elmén belül a környezetból származó, különbözô típusú információk feldolgozását több, funkcionálisan különbözô (vagyis területspecifikus) mechanizmus látja el (Boyer és Barrett, 2005; Hirschfeld és Gelman, 1994). Ennek megfelelốen a vallást is több különbözô, egymástól független, a moduláris modell által 
posztulált, információspecifikus kognitív mechanizmusnak a múködésére próbálják visszavezetni (Boyer, 2001; Tremlin, 2006). Részleteiben mindezt a 2.3. alfejezetben tárgyalom.

A fenti, fragmentáló magyarázó stratégiát követô keret elfogadásának az egyik fontos következménye a vallás mint jelenség általános és egységes definícióinak a megkérdôjelezése (Boyer és Bergstrom, 2008; Sosis, 2009). Ehelyett a CSR abból indul ki, hogy a vallás fogalma elsôsorban egyfajta gyújtônév: olyan heterogén kulturális jelenségekre vonatkozik, amelyek nem fedhetôek le egyetlen koherens és általános definícióval sem. Boyer (2011) szerint a jelenségek három szintjét érdemes megkülönbözetni: a vallásos hiedelmek és viselkedésformák szintjét, a körülöttük kialakuló kulturális tradíciókat, végül az elóbbiekhez kapcsolódó intézményrendszereket (mely utóbbi szint csak a komplex, állami társadalmakban jelenik meg). Így nem igazolhatóak a vallástudományoknak azok a megközelítései sem, amelyek a vallást mint egységes szimbólumrendszert vagy világképet írják le. Ehelyett a vallásnak a fogalma inkább egy konvencionális eszköz, amelynek elsôsorban heurisztikai értéke van.

\subsection{A vallás középpontjában ágensreprezentációk állnak}

Bár ahogy fentebb szó volt róla, a CSR a vallást nem tekinti egy körülhatárolható, egységes jelenségnek, másrészt mégis közel kerül egy általános vallásdefiníció kialakításához. Az irányzat képviselôinek központi tézise szerint ugyanis a vallások középpontjában álló istenképzetek kognitív nézôpontból valójában ágensreprezentációknak (ágensekre vonatkozó képzeteknek) tekinthetóek (Barrett, 2004; Boyer, 2001; Guthrie, 1993; Pyysiäinen, 2009). Mindezek leírására használják általánosító módon a „természetfeletti ágensek” (supernatural agents) kifejezést. A kognitív magyarázatok nézôpontjából a monoteista és politeista vallások különféle istenképzetei, illetve a világ csaknem minden vallásában elóforduló szellem-, ôs- és lélekképzetei egyaránt ilyen ágensreprezentációk.

Vagyis az ágencia felismerése és az ágensekre vonatkozó következtetések tekinthetôek a vallásért felelôs legfontosabb mentális folyamatoknak, amelyból kiindulva kidolgozható a vallás kognitív magyarázata. Ennek központi kérdése, hogy milyen hasonlóságok és eltérések állnak fenn a vallásos ágensreprezentációk és más, hétköznapi (például az emberi személyekre vonatkozó) ágensreprezentációk között. A kognitív magyarázatok szerint a „természetfeletti ágensek” mentális reprezentációi (istenek, szellemek) kettôs struktúrával jellemezhetốek (Boyer, 2001; Tremlin, 2006). Egyrészt, rendelkeznek a hétköznapi (vagyis emberi) ágenciára is jellemzô sajátosságokkal, tehát intencionalitással, tudattal, észleléssel, vágyakkal. Másrészt rendelkezhetnek bizonyos természetfeletti (nem hétköznapi) tulajdonságokkal is, mint a testnélküli létmód, idôbeli állandóság (halhatatlanság), távolból okozás képessége. Az ilyen tulajdonságokra az „intuitív vélekedésekkel ellentétes” terminusa (az eredetiben: „counterintuitive”) vált használatossá (Boyer, 2001 és 2003) - ennek pontos ismertetésére lentebb, a 3. alfejezetben térek ki. 


\subsection{A vallásos ágensreprezentációk az emberi kogníció néhány meghatározott területével hozhatóak kapcsolatba}

A fenti, az ágenciát és ágensreprezentációkat a vallás középpontjába helyezô magyarázatokon belül (Guthrie, 1993; Boyer, 2001; Barrett, 2004) a vallást az emberi kogníciónak (és közvetve a kognitív pszichológiának) az alábbi két nagyobb részterületével hozhatjuk kapcsolatba:

a) A szociális kogníció területe: Ide tartoznak azok a kognitív folyamatok, amelyek az ágencia kognitív feldolgozásában is részt vesznek, elsôsorban maga az ágenciafelismerés, mely a CSR szerint hajlamos a túlfokozott múködésre: ott is ágenseket feltételez, ahol azok nincsenek jelen („hiperaktív ágensfelismerés” - lásd: Barrett, 2004). A vallásos istenképzeteknek - a kulturális különbségeken túl - a legfontosabb kognitív attribútuma, hogy elmével rendelkeznek (Boyer, 2001). Ezért az elmeteória és elmeolvasás mechanizmusai is kapcsolatba hozhatóak az ágencia felismerésével, és így a vallással is (Barrett, 2004; Tremlin, 2006). Szintén fontos az istenképzetekhez kapcsolódó céltulajdonítás (vagy tervezeti hozzáállás), melyre a „teleologikus következtetés” kifejezés használatos (Kelemen, 2004). A fenti alapokra épülnek rá a legtöbb vallásban (mint a kereszténységben is) azok a hiedelmek, hogy az istenség folyamatosan elvárásokat alakít ki az emberek cselekedeteivel és szándékaival kapcsolatban (Bering, 2011). Ezért válhat a vallás egyik fố evolúciósan adaptív funkciójává a szociális és morális normákat követô magatartás megerôsítése - a természetfeletti felvigyázás, jutalmazás és büntetés koncepcióinak segítségével (Johnson és Bering, 2006; Pyysiäinen és Hauser, 2010).

b) Az intuitív tudásrendszerek területe: Ahogy arra már utaltam, szintén magyarázatot igényelnek a vallásos ágensképzetek „természetfeletti” tulajdonságai is - melyek az emberi kogníció külvilágra vonatkozó „intuitív vélekedéseivel ellentétesek”. Ez a kifejezés az emberi elme intuitív megismerô rendszereinek (népi fizika, népi biológia, népi lélektan) a múködési módjában gyökerezô, intuitív vélekedésekre utal (Boyer és Barrett, 2005; Hirschfeld és Gelman, 1994). Atran (2002) és Boyer (1993, 2001, 2003) is abból indul ki, hogy ezek a tudásrendszerek az észlelt jelenségeket automatikusan öt alapszintû „ontológiai kategóriába” (tárgyak, eszközök, növények, állatok, személyek) sorolják be. Az elmének tehát elôzetes (intuitív) elvárásai vannak arról, hogy az e kategóriákba sorolható entitások milyen alapvetô tulajdonságokkal rendelkezhetnek. A vallásos ágensképzetekre viszont a világ számos kultúrájában az jellemezô, hogy tulajdonságaik ellentmondásban állnak az intuitív tudásrendszereknek a felsorolt kategóriákra vonatkozó „ontológiai elvárásaival”.

A vallásos képzeteknek az ilyen, „intuíciókkal ellentétes” tulajdonságaira vonatkozó hiedelmek kétféle következtetési folyamat során alakulhatnak ki. Egyrészt, az ellentétes „ontológiai kategóriákra” (például élő-élettelen, ember-állat) jellemzô tulajdonságoknak a más kategóriára való átvitele útján (2. ábra). Másrészt, az istenképzetek néhány további „nem elvárt” tulajdonsággal is rendelkeznek: testnélküliség, láthatatlanság, mindent tudás, távolból okozás, halhatatlanság. E tulajdonságok mögött közös tényezóként azok a kognitív következtetések (hiedelmek) állnak, amelyek az elme/ szellem/lélek elsóbbségét feltételezik a fizikai testtel szemben. E hiedelmek forrását az intuitív és innát „test-lélek dualizmus” jelenti, amely már nagyon korai életkorban is jellemzô az emberi kognícióra (Bloom, 2007; Kelemen, 2004). 
- A CSR szerint a vallásos képzetek elsốsorban ágensekre vonatkozó képzetek (reprezentációk), melyekhez az emberi megismerési folyamatoknak (népi fizika, népi biológia, népi pszichológia) az „intuitív elvárásait” megsértő tulajdonságok (testnélküliség, halhatatlanság, mindent tudás stb.) kapcsolódnak. Emellett széleskörúen jellemzó rájuk az eltérô „ontológiai kategóriákhoz" (az itt bemutatott példákban az ember-állat és az emlős-madár kategóriákhoz) tartozó tulajdonságoknak az átvitele (újra kombinálása) is.

- Mindezek a jellemzốk a vallásos képzeteket egyúttal az emberi elme számára vonzóvá és figyelemfelkeltốvé is teszik (kognitív optimum). Ez hozzájárul a sikeres kulturális továbbadásukhoz, hatékonyabb memorizálásukhoz és fennmaradásukhoz.

- A térben és idôben is távol esố kultúrák vallásos képzetei között fennálló, néha meglepô hasonlóságok tehát az alapvetố emberi kognitív diszpozíciókra vezethetôek vissza (balra: barlangrajz a felsốpaleolitikumból, Trois-Fréres barlang, Franciaország; jobbra: asszíriai Lamasszu (védố istenség) szobra az i. e. 8. századból, Dur-Sharukkin - ma Khorzabad, Irak).
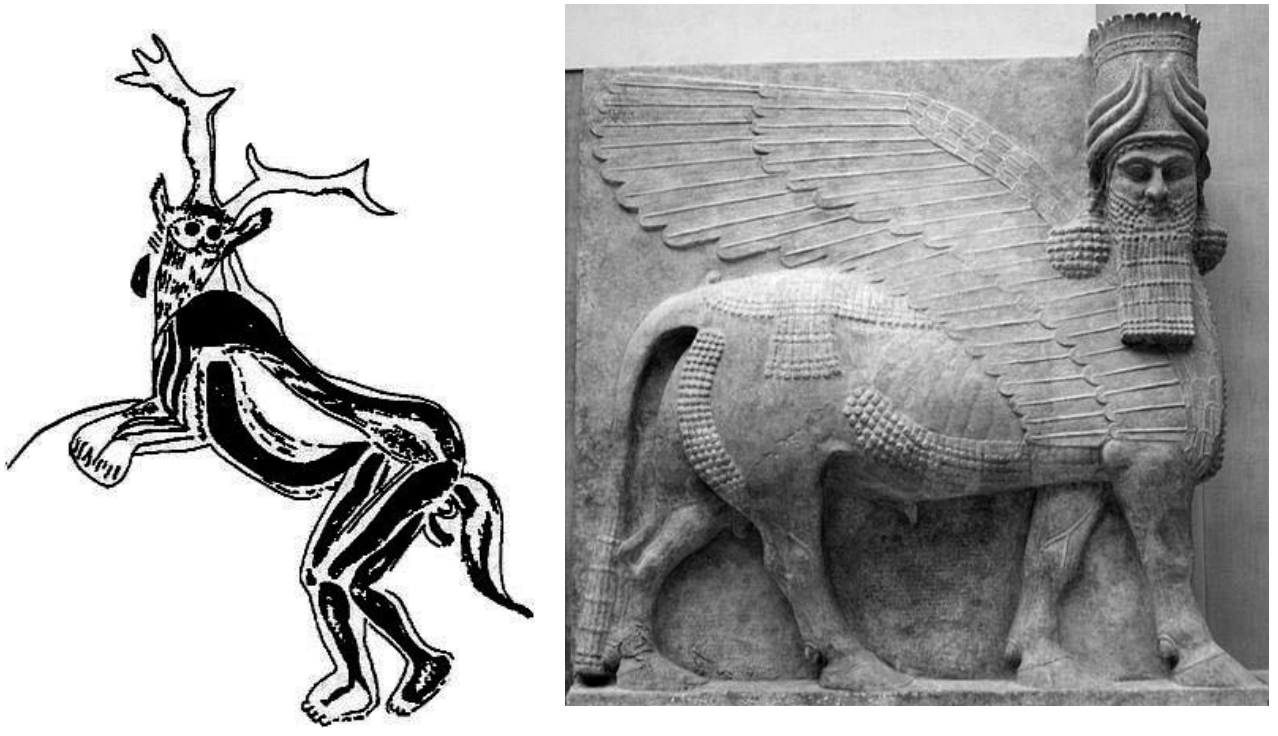

2. ábra. A vallásokban elôforduló „természetfeletti ágensek” tulajdonságainak kognitív magyarázata (a képek forrása: Wikimedia Commons)

\subsection{Evolúciós keretek alkalmazása: a vallást megalapozó kognitív mechanizmusok az emberi evolúció folyamata során alakultak $\mathrm{ki}$}

A vallás kognitív elméleteinek célja magyarázatot adni arra is, hogy az emberi elme hogyan és miért hozza létre a vallást - azaz a fenti értelemben vett „természetfeletti ágensek" létét feltételezô vélekedések és hiedelmek rendszerét. Az 2.1. alfejezetben tárgyalt moduláris szemléletbôl az is következik, hogy az emberi kogníció számos tulajdonságát az ember evolúciós múltjába illeszkedô, evolválódott sajátosságnak tekinthetjük (Tooby és Cosmides, 1992). Ezt az evolúciós elméleti keretet a CSR képviselôi is elfogadják a vallásos képzetek és viselkedésformák iránti hajlam vizsgálata során. A vallásra vonatkozó megfelelô kognitív magyarázat ezért egyúttal evolúciós magyarázat is 
lesz, vagyis azonosítani kell tudnia a vallásos viselkedésnek az evolúció során előnyös adaptív funkcióit ${ }^{3}$ is (Atran, 2002; Boyer, 2003; Boyer és Bergstrom, 2008).

Ezen a ponton érdemes kitérni a vallás funkciójára vonatkozó „,adaptáció vagy melléktermék” vitára is (Pyysiäinen és Hauser, 2010; Szabó, 2016). A CSR által preferált evolúciós magyarázat ugyanis a „melléktermék hipotézis”, mely szerint a vallás a más célokra evolválódott kognitív adaptációk mellékterméke - tehát nem rendelkezik saját, azonosítható adaptív funkcióval (Atran, 2002; Boyer, 2001). Az ilyen magyarázatok szerint a vallást az egyéni elmékben múködô, automatikus és önkéntelen kognitív sémák (észlelési, következtetési folyamatok) hozzák létre, amelyeknek eredetileg „hétköznapi” funkciójuk van: a környezet eseményeire vonatkozó észlelés és következtetés (Boyer, 2003). Vagyis a vallás a hétköznapi kognitív sémák „túlmúködésének” a következménye: egyfajta téves kogníció, amely a hétköznapi (fizikai) oksági tényezôk helyett a természetfeletti ágensekkel (istenekkel) kapcsolatba hozható okokkal köti össze az észlelt eseményeket (Barrett, 2004, Guthrie, 1993).

Azonban a fenti, a CSR által képviselt „melléktermék hipotézissel” részben ellentétes, részben azokat kiegészító megközelítések is léteznek jelenleg. Ezekre a „vallás evolúciós magyarázatai” elnevezést használhatjuk (Wilson és Green, 2012; Szabó, 2016). Ezen elméletek szerint a vallásos viselkedés egyes elemei valódi, evolúciós értelemben vett adaptációk (Sosis, 2009). Vagyis a vallásoknak olyan saját adaptív funkcióik is vannak, amelyekre a by-product hipotézis nem nyújt elégséges magyarázatot. Ezt igazolhatják a vallás proszociális (altruista) és kooperatív viselkedést befolyásoló hatásának (vagyis tulajdonképpen az etikai és morális funkciójának) a kimutatására irányuló, empirikus kutatások is (Johnson és Bering, 2006; Pyysiäinen és Hauser, 2010). Ugyanakkor, bár ez a jelen írásnak nem témája, a kognitív és az evolúciós megközelítések nem zárják ki egymást, elméleti szinten valójában összekapcsolhatóak (Szabó, 2016).

\subsection{Kultúra és kogníció: a kognitív feltételek a vallásos képzetek kulturális elterjedését is befolyásolják}

A 2.3. alfejezetben tárgyalt magyarázatok az egyéni kognitív folyamatok szintjén vizsgálták a vallásos képzetek kialakulását. Ugyanakkor a vallásos hiedelmek és képzetek jelenléte a kultúrák szintjén is alapvetôen egységes formában, széles körben kimutatható. Mindez egy metodológiai problémát is felvet, mivel szükségessé teszi az egyéni kogníció szintje és a kulturálisan érvényes vallásos reprezentációk szintje között érvényesülő összefüggések megértését is (Boyer, 2001; Atran, 2002). Ez az egyik olyan pont egyúttal, ahol a „kognitív vallástudomány” jelentôsen eltér a „valláspszichológia” korábbi irányzataitól (Barrett, 2011). Míg az elóbbi a különbözô kultúrák vallásai mögött is kimutatható, vagyis univerzális kognitív szabályszerúségekre helyezi a hangsúlyt, addig az utóbbi a kultúra szintje helyett inkább az egyéni pszichológiai folyamatok szintjén vizsgálja a vallást (például a személyes istentapasztalatot és spiritualitásélményeket, vagy a megküzdési folyamatokat).

Egy viselkedésforma akkor tölt be evolúciósan adaptív funkciót, ha növeli az egyed sikeres túlélésének vagy szaporodásánek esélyeit. 
Ezért a CSR számára alapvetô kérdés, hogy az egyéni elmékben kialakuló vallásos képzetek miképpen maradnak fenn tartósan, generációkon át, és válnak kulturális tradícióvá. Ugyanakkor az irányzat e kérdés vizsgálata során ismét csak az egyéni elmékhez köthetô, kognitív pszichológiai mechanizmusok leírásából indul ki (Barrett, 2000, 2017). Ugyanis a vallásos képzetek kulturális továbbadását és felidézését is alapvetôen a kognitív prediszpozíciók (emlékezeti és következtetési folyamatok) határozzák meg. Vagyis a CSR szerint a vallástörténet által leírt vallási tradíciók különbözôsége és sokfélesége is visszavezethetô a fajspecifikusnak tekinthetô (univerzálé jellegû) kognitív mechanizmusokra (Guthrie, 1993; Boyer, 2001; Barrett, 2004, 2011, 2017).

A fenti kérdések középpontba állítása terén Sperber (2001) és az ó „epidemológiai modellje” volt jelentôs hatással az irányzatra. E modell a mentális reprezentációk kulturális elterjedésének két alapvetô kognitív feltételét határozta meg. A kulturális sikeresség egyik ilyen feltétele, hogy az egyes (vallásos) reprezentációk emlékezeti felidézése minél kevesebb erôfeszítést igényeljen. A másik feltétel szerint a sikeres reprezentációk jelentôs kognitív hatással (relevanciával és figyelemelkeltô jelleggel) kell rendelkezzenek.

Ezekhez a feltevésekhez kapcsolódik Boyer (2001, 2003) elmélete a „minimálisan az intuitív vélekedésekkel ellentétes" (minimally counterintuitive) képzetek iránti kognitív fogékonyságról. Ez az elmélet azt feltételezi, hogy a leghatékonyabban memorizálható vallásos képzetek azok, amelyekben az „intuitív vélekedésekkel ellentétes” tulajdonságok száma csupán minimális, mivel az ilyen jellegú tulajdonságok feldolgozása kognitív értelemben már túlzottan költséges. Napjainkra e témakör az irányzat egyik legfontosabb kutatási területévé vált a kísérleti vizsgálatok szempontjából is (Norenzayan, Atran, Faulkner és Schaller, 2006; McCauley, 2017).

A fentiektôl független, de szintén nagy hatású Whitehouse (2000) elmélete „a vallásosság módozatairól”. Az elmélet szerint a vallásos rítusoknak két alapmódozata különböztethetô meg, melyek a kulturális átadás eltérô módjaira épülnek. A „képi módozat" az olyan drámai hatású rítusokra (például beavatásokra) épül, melyek erôs érzelmi arousalt kiváltva, az epizodikus memóriát aktiválják. Ezzel ellentétes a „doktrinális módozat", ahol az állandóan ismétlődô rituálék a doktrinálisan rögzített vallási tanítások szóbeli felidézésével is társulnak, mindez elsôsorban a szemantikai memóriát veszi igénybe.

\section{A KOGNITÍV VALLÁSELMÉLETEK ALKALMAZÁSA: NÉHÁNY PÉLDA}

A „kognitív vallástudomány” legkorábbi idôszakát fooleg az elméleti modellek dominanciája jellemezte, azonban e mellett, már az 1990-es évek végétôl megjelentek a fejlődéspszichológiai ihletésú, kísérleti vizsgálatok is (Barrett és Keil, 1996). Vagyis az irányzatnak célját képezte a vallásra vonatkozó elméleteknek a kísérleti megközelítéssel való összekapcsolása is (McCauley, 2017). Ennek egyik eleme volt (a Piaget-i tradíció nyomán) a gyermeki elme és a felnôttkori kogníció közötti eltérések célzott vizsgálata az istenképzetek esetében (Kelemen, 2004; Barrett, 2012; Bering, 2011). Egy másik elem pedig a kultúraközi összehasonlítás alkalmazása, amikor ugyanazokat a vizsgálatokat a különbözô államok (vagy akár kontinensek) eltérô kulturális hátterú 
(azaz eltérô vallású) népességeiből származó résztvevôkkel is elvégzik (Barrett, 1998; Knigth, Sousa, Barrett és Atran, 2004; Hornbeck és Barrett, 2017). Mindez tehát az alább tárgyalandó példák legtöbbjére is érvényes.

Itt érdemes kiemelni az emberi kogníció manapság egyre népszerúbb kettôsrendszer elméleteinek (például: Sperber és Mercier, 2015, Kahneman, 2012) a vallás kognitív magyarázataiban játszott szerepét is. Ezek az elméletek két eltérô kognitív feldolgozási módot különböztetnek meg: egyrészt az automatikusan lezajló (intuitív, nem reflektált, gyors, implicit) kognitív folyamatokat, másrészt a tudatosuló (reflektált, lassú, figyelmi erôfeszítést igényló, explicit) folyamatokat. A kétféle rendszer jelenléte az emberi kogníció számos területén kimutatható (észlelés, következtetés, döntéshozás, tudás és hiedelmek). A CSR szerint mind a vallás evolúciós (filogenetikus) kialakulásáért, mind pedig a vallás egyének általi (ontogenetikus) elsajátításáért is jelentôs részben az elsố típusú, intuitív folyamatok a felelôsek (Boyer, 2001; Tremlin, 2006; Pyysiäinen, 2009). Ez természetesen azt is jelenti, hogy a tudatos, reflektált kognitív folyamatok szerepe csak másodlagos a vallásos hiedelmek és következtetések kialakítása során. Vagyis a kulturális reprezentációk struktúráját nagymértékben meghatározzák az elmén belül lezajló, jelentôs részben intuitív kognitív folyamatok is (Sperber, 2001; Boyer, 2001). A kísérleti kutatásoknak ezért fontos célja e kérdéskör vizsgálata is.

A fenti megjegyzéseket követôen nézzük meg mindezt néhány konkrét kutatási terület példáján is. Elsố példánkat az istenképzetekkel mint ágens reprezentációkkal összekapcsolódó tulajdonságok (attribútumok) vizsgálatának területe jelenti. Az egyik korai kutatás e téren a „teológiai korrektség” elnevezéssel illetett jelenséghez kapcsolódott. Ezzel a fogalommal J. Barrett és kollégái (Barrett és Keil, 1996; Barrett 1998) azt a tendenciát írták le, hogy számos kultúrában egyazon istenségre vonatkozóan is kétféle, egymással konfliktusban álló istenképzet van jelen egyidejüleg. Az isteni attribútumok egyik típusát az absztrakt és univerzális tulajdonságok jelentik (mindentudás, mindenütt való jelenlét, idôtlenség), a másik típust pedig az antropomorf, személyekre jellemzô tulajdonságok (a saját perspektívánk által korlátozott tudás és érzékelés). A kereszténység irányzatai (és más nagy vallási tradíciók) által intézményesen is rögzített, „teológiailag korrekt” istenfogalmak esetében az elsố típusú tulajdonságok a kulturálisan mérvadóak. Ennek ellenére a tulajdonságok két típusának konfliktusa jól kimutatható volt az olvasott történetek felidézésére vagy újramondására épülő kísérletek során (Barrett és Keil, 1996; Barrett, 2004). A résztvevôk az absztrakt tulajdonságok helyett önkéntelenül is emberi sajátosságokat (pl. egy idôben csak egy helyen való tartózkodás) építettek be a történetekbe. Mindez azzal magyarázható, hogy a kognitív feldolgozási folyamatok kettôsrendszer elméletének megfelelően, a hívők intuitív hiedelmei a narratívák felidézése során felülírták a kultúra által jóváhagyott, de csak erôfeszítés útján felidézhetô reflektív hiedelmeket (teológiai doktrínákat).

E kutatási terület egyik legérdekesebb témáját az „elmeteória” vagy elmeolvasás és a vallás kapcsolatának a kísérleti vizsgálata jelenti (Barrett, Richert és Driesinga, 2001; Knigth és mtsai, 2004; Richert és Barrett, 2005). Az „elmeteória” a mások szándékaira vagy motivációira vonatkozó feltételezések kialakításának képessége. Az isteni attribútumok egy részét azonban szintén a más ágensek elméjére, intencionalitására és mentális állapotaira vonatkozó feltételezéseknek (reprezentációknak) is tekinthetjük (Bering 2006, 2011; Barrett, 2012). A kereszténység esetében ilyen attribútumok például 
a mindentudás, a tévedhetetlenség és a korlátlan érzékelés képessége („Isten mindent lát”). Az „elmeteória” hétköznapi múködése szempontjából, ezek a vallásos képzetek erôsen az „intuitív vélekedésekkel ellentétes” jellegúek. E miatt azt várnánk, hogy kognitív feldolgozásuk megterhelô, ami a kulturális elterjedésüket is korlátozottá teszi.

Az „elmeteória” gyerekkori kialakulására vonatkozó fejlôdéspszichológiai kutatások (Wellman, Cross és Watson, 2001) azonban egy másik magyarázat lehetôségét is felvetették. Ugyanis, hozzávetôleg négyéves korig, a gyermekek még hajlamosak arra, hogy minden „emberi ágens” esetében feltételezzék a hamis vélekedésre való képesség hiányát, ami voltaképpen a mindent tudás állapotát jelenti. Emiatt Barrett és Richert (2003) szerint megfogalmazható egy olyan „elôkészítettségi hipotézis”, mely szerint a korai gyermekkorban az elme kiemelten fogékony bizonyos típusú (a felnôttek számára ellentmondásos) vallásos képzetekre. Mégpedig azokra, amelyek középpontjában az olyan természetfeletti ágensek állnak, melyek a hétköznapi emberi ágensekét meghaladó, teljes körû tudással és érzékeléssel bírnak:

„a korai fejlôdés során megjelenô 'mentális készségek' (mint az elmeolvasás is) nem kizárólagosan emberek megértésére szolgálnak, és ezért elôsegítik az ábrahámi monoteizmus istenképzetéhez tartozó jellemzóknek az elsajátítását és használatát is" (Barrett, 2004, 77). ${ }^{4}$

Vagyis e megközelítés szerint a gyermekkori kognitív fejlődés kezdetén az elmeteória, illetve az ágencia feldolgozásához kapcsolódó más kognitív mechanizmusok is (ágensdetektálás, teleologikus vagyis tervezeti hozzáállás) erősen „túlbecsülik” mind az emberi, mind a nem emberi ágensek képességeit és hatáskörét (Bloom, 2007; Kelemen, 2004; Barrett és Richert, 2003; Richert és Barrett, 2005; Knigth és mtsai, 2004). Tehát a kogníció és a kultúra között egyfajta kölcsönös interakcióról beszélhetünk: a keresztény kultúrkörben uralkodó vallásos képzetek valójában kognitív értelemben jól illeszkednek a korai gyerekkorra jellemzô, az ágencia iránt erôsen szenzitív következtetési stratégiákhoz. Továbbá, a késôbbi fejlődés során a gyermekek képessé válnak rá, hogy a különbözố típusú ágenseknek (például a szüleiknek, a Télapónak vagy Istennek) eltérô típusú mentális állapotokat tulajdonítsanak.

Az istenképzetek után a második példánk a halál utáni életre (a személyiség és/ vagy lélek halhatatlanságára) vonatkozó képzetek területe lesz (Bering, 2006; Bloom, 2007; Barrett, 2012). A kognitív elméletek szerint - az istenképzetekhez hasonló módon - a halottakra és halál utáni továbbélésre vonatkozó képzetek is alapvetôen ágensreprezentációk (Bering, 2006, 2011). Itt a kérdés tehát az, hogy az emberi kogníció intuitív elvárásai milyen hiedelmeket alakítanak ki egy másik személyrôl annak halála után - miért állhatnak konfliktusban kognitív értelemben ezek a hiedelmek a testi halál biológiai tényeivel. A kísérleti vizsgálatok itt egy olyan tendenciát mutattak ki, amely bár eltérô mértékben, de az alanyok vallási hátterétôl vagy éppen annak a hiányától függetlenül (például az ateisták esetében) is érvényesült (Bering, 2006). E sze-

4 „early-developing mental tools (such as the Theory of Mind [ToM]) are not specifically for representing humans and, in fact, actually facilitate the acquisition and use of many features of God concepts of Abrahamic monotheisms." 
rint a gyerekek és felnôttek is hajlamosak az inkább a tudati folyamatokhoz kötôdô mentális állapotoknak (gondolkodás, érzelmek, vágyak) a folytonosságát feltételezni az egyén biológiai halálát követően. Ezzel szemben az inkább a testi folyamatoktól függố mentális állapotokra (például éhség, szomjúság) vonatkozóan jóval kisebb mértékben alakítanak ki ilyen feltételezéseket. Bering (2011) szerint ennek egyik lehetséges magyarázata, hogy az emberi elme veleszületett módon képtelen a mentális állapotok teljes megszúnésének a „szimulációját” létrehozni. Egy további kérdés, hogy a halhatatlansággal kapcsolatos hiedelmek mennyiben tölthetnek be evolúciósan adaptív funkciót. Itt vizsgálták egyrészt e képzetek pozitív hatását az egyének mentális egészségére és jólétére (McClain-Jacobson és mtsai, 2004), másrészt, a társadalmak szintjén, az „élóket megfigyelő halottak” jellegú hiedelmek a kísérletek által is kimutatható, pozitív hatást gyakorolhatnak az erkölcsi normák követésére, a segítésre és kooperációra (Bering, 2006; Pyysiäinen és Hauser, 2010).

A fenti két, részletesebben tárgyalt példa mellett a kognitív magyarázatok alkalmazására a vallás számos további részterületével kapcsolatban sor került. Így megemlíthetôek a rituális cselekvésre (Lawson és McCauley, 1990), a teleologikus hozzáállásra és az isteni teremtésbe vetett hitre (Kelemen, 2004), a vallásos megszállottságra (Cohen, 2007), a mágiára (Sørensen, 2006), az isteni büntetés és jutalmazás képzeteire (Norenzayan, 2013) vonatkozó magyarázatok is.

\section{AZ IRÁNYZAT ÉRTÉKELÉSE}

A „kognitív vallástudomány” mint irányzat legfớbb teljesítménye, hogy egy átfogó, koherens és egységes elméleti keretben helyezi el a vallást és az emberi vallásos viselkedést. A vallás iránti fogékonyságot (hajlamot) mint az evolúció által kialakított (evolválódott) emberi kogníció elválaszthatatlan részét vizsgálja és magyarázza. Ezt a kutatási programot egyetlen általános, központi hipotézisben lehet összegezni (Boyer, 1993; Hornbeck és Barrett, 2017). E szerint a vallást - és részjelenségeit - az emberi kogníció naturális (azaz természetes, veleszületett jellegü) múködése hozza létre. Vagyis a vallások önkéntelenül is „természetes” (naturális) módon gondolkodnak a „természetfelettiról".

A naturális kognitív folyamatokra a következôk jellemzôek (McCauley, 2011; Barrett, 2000, 2012): a korai életszakaszban lezajló fejlődés során alakulnak ki („veleszületett” prediszpozíciók mentén); megnyilvánulási módjaik az emberi fajon belül egységes jellegúek, így mind az egyéni, mind a kulturális különbségek is másodlagosak; múködésüket tekintve inkább intuitív, mint tudatos jellegúek és nagyrészt tartalom- és feladatspecifikusak. A CSR szerint feltételezhetô, hogy minél inkább megfelel egy vallásos képzet az emberi kogníció fenti jellemzôinek, annál tartósabb és szélesebb körú kulturális elterjedésére számíthatunk (Barrett, 2011, 2017).

Ezen a ponton érdemes még egyszer visszatérni az irányzat vallásdefiníciójának a kérdésére. A társadalomtudományokban (Durkheim, 2002) és a vallástörténetben (McCutcheon, 1997) ugyanis erôteljesen érvényesül egy olyan megközelítés, amely a szent és a profán megkülönböztetése mentén határozza meg a vallást, és az egyéni vallásos tapasztalatot is. E szerint a szakrális (szent) minôségileg más, idôben állandó 
és transzcendens, vagyis az egyéni vallásos tapasztalat és élmény nem visszavezethetô a hétköznapi (profán) tapasztalatokra. Ezzel az állásponttal szemben a CSR programját a vallásnak (és az istenképzetekhez kapcsolódó attribútumoknak) az emberi kogníció következtetési és észlelési folyamataira való oksági visszavezetése jelenti (Boyer, 2001).

E tekintetben a „kognitív vallástudománynak” a vallásról alkotott képét leginkább két másik kortárs irányzatéval állíthatjuk párhuzamba, melyek középpontjában szintén a vallás naturalista értelemben vett, fizikalista oksági magyarázata áll. Ezek egyikét a vallás evolúciós magyarázatainak a területe jelenti (Sosis, 2009, Wilson és Green, 2012), melyet a 2.4. alfejezetben már tárgyaltunk. E kutatási terület az egyes vallások meghatározó sajátosságait a természetes szelekció, illetve az emberi kulturális evolúció és csoportszelekció által kialakított, adaptív funkciókra vezeti vissza oksági értelemben (Sosis 2009). A két irányzat különbségei ellenére a vallásnak az ilyen, evolúciós indíttatású elméletei alapvetôen összeegyeztethetôek a kognitív elméletekkel, mivel mindkét megközelítés elfogadja az emberi elme modularitásának és evolúciós eredetének a téziseit (Boyer, 2001, 2003; Boyer és Bergström, 2008).

A másik párhuzamos területet az emberi elme vallásos múködésének a neuropszichológiai és neurofarmakológiai alapjaira vonatkozó kutatások képviselik, melyekre összefoglalóan a „neuroteológia” elnevezéssel is szokás utalni (Sands, 2009). Ezen irányzat az egyéni vallásos élmények során fellépố agyi aktivitást a modern orvosi mérési és képalkotó eljárásokkal vizsgálja. Vagyis itt is egy naturalista értelemben vett, oksági visszavezetésen alapuló kutatási programról beszélhetünk, mely meghatározott agyi területek aktivitásával kapcsolja össze az olyan komplex pszichés állapotokat, mint a meditáció, transz, látomások, spirituális jelenlétérzés, istenélmény (McNamara, 2009; Newberg, 2007). Ugyanakkor, a részben hasonló naturalista megközelítés ellenére, a CSR képviselôi csak korlátozott szerepet tulajdonítanak az ilyen jellegú, „módosult tudatállapotoknak" (Boyer, 2001). Ennek oka, hogy az antropológiai kutatások többsége alapján az ilyen élmények szerepe korlátozott: a vallásos képzetek kulturális elterjedésére a legnagyobb hatást ugyanis más egyének állításai és hiedelmei gyakorolják, már a gyerekkortól kezdôdően (Boyer, 2003). Ezért a „neuroteológia” jelenlegi megközelítésein belül csak korlátozottan hidalható át a személyes vallásos tapasztalat és a kulturális jelenségek szintje közötti választóvonal.

Végül zárszóként a „kognitív vallástudomány” egy tágabb, a vallás témáján túlmutató perspektívában is értékelhetô. Ez esetben abból érdemes kiindulni, hogy az irányzat alapvetốen osztja az evolúciós pszichológia képviselőinek a programját, amely egyrészrôl a humán- és társadalomtudományok, másrészrôl az evolúciós viselkedéstudományok elméleti és módszertani integrációját tartja célkitúzésének (Tooby és Cosmides, 1992; Wilson, 1998). E programnak megfelelốen az 1990-es és 2000-es évek folyamán számos olyan új kutatási és elméleti irányzat alakult ki, amelyekre összefoglaló módon alkalmazhatjuk az emberi kulturális viselkedés „evolúciós és kognitív elméletei” megnevezést (Slingerland és Collard, 2012).

A CSR irányzata tehát e terület egyik képviselőjének tekinthetô (Slingerland és Bulbulia, 2011). Az ilyen, evolúciós-kognitív elméleteknek számos különbözô változata jelent meg, két metodológia alapfeltevést azonban minden ilyen irányzat elfogad (Tooby és Cosmides, 1992; Pinker, 2002). Egyrészt feltételezik, hogy a kulturális visel- 
kedési formák oksági értelemben a saját neurokognitív alapjaikra vezethetôek vissza. Másrészt elfogadják az evolúciós elméleti perspektíva alkalmazásának a szükségességét, mivel a neurokognitív mechanizmusok az emberi evolúció során, a legtöbb esetben adaptációs folyamatok során alakulhattak ki.

A fenti feltevéseket képviselô irányzatok ma már számos olyan elméleti területre kiterjednek, amelyekre vonatkozóan korábban a humántudományok (vagyis a társadalom- és kultúratudományok) kizárólagos illetékességgel rendelkeztek (Wilson, 1998; Slingerland és Collard, 2012). Így a vallás mellett ma már beszélhetünk az „emberi természet” további alapvetô aspektusainak az evolúciós és kognitív elméleteirôl. Ezek között megtalálhatóak a morális normák és viselkedés (Krebs, 2011), a társas és a gazdasági együttmúködés (Bereczkei, 2009), a mûvészetek (Davies, 2013), az irodalom és a történetmondás (Carroll, 2004), a kultúra és kulturális tanulás (Tomasello, 2009) elméletei is. Ráadásul az itt említett területek egy része szintén az önálló tudományos irányzattá vagy diszciplínává válás küszöbén áll. Ezért jövôbeni szerepének alakulásától függetlenül a „kognitív vallástudomány” jelentôsége is leginkább abban rejlik, hogy az egyik sikeres példáját kínálja a kognitív-evolúciós irányú magyarázatok alkalmazásának az emberi viselkedés egy olyan összetett területére is, mint a vallás.

\section{IRODALOM}

Atran, S. (2002). In Gods We Trust: The Evolutionary Landscape of Religion. Oxford: Oxford University Press.

Barrett, J. L. (1998). Cognitive constraints on Hindu concepts of the divine. Journal for Scientific Study of Religion 37, 608-619.

Barrett, J. L. (2000). Exploring the natural foundations of religion. Trends in Cognitive Sciences, 4, 29-34.

Barrett, J. L. (2004). Why Would Anyone Believe in God? Walnut Creek, CA: AltaMira Press.

Barrett, J. L. (2011). Cognitive science of religion: Looking back, looking forward. Journal for the Scientific Study of Religion, 50(2), 229-239.

Barrett, J. L. (2012). Born believers: The science of children's religious belief. New York: Free Press.

Barrett, J. L. (2017). On Keeping Cognitive Science of Religion Cognitive and Cultural. In L. H. Martin, \& D. Wiebe (Eds), Religion Explained?: The Cognitive Science of Religion after Twenty-five Years (pp. 168-176). London, New York: Bloomsbury.

Barrett, L. J., \& Keil, F. C. (1996) Anthropomorphism and God concepts: Conceptualizing a non-natural entity. Cognitive Psychology, 31(3), 219-247.

Barrett, J. L., \& Richert, R. A. (2003). Anthropomorphism or preparedness? Exploring children's God concepts. Review of Religious Research, 44(3), 300-312.

Barrett, J. L., Richert, R. A., \& Driesenga, A. (2001). God's beliefs versus mother's: The development of nonhuman agent concepts. Child Development, 72(1), 50-65.

Bereczkei, T. (2009). Az erény természete. Önzetlenség, együttmüködés, nagylelkúség. Budapest: Typotex Kiadó.

Bering, J. (2006). The folk psychology of souls. Behavioral and Brain Sciences, 29(5), 453-498.

Bering, J. (2011). The belief instinct: The psychology of souls, destiny, and the meaning of life. New York: Norton.

Biró T. (2011). Értelek, értelek... de mirôl beszélsz?? A keresztény-zsidó párbeszéd a kognitív vallástudomány perspektívájából. In Dobos Károly D., Fodor Gy. 
(szerk.), „Vizió és valóság”: A Pázmány Péter Katolikus Egyetemen 2010. október 28-29-én „A dialógus sodrában...” címmel tartott zsidó-keresztény konferencia elóadásai (pp. 51-71). Budapest: Új Ember-Márton Áron Kiadó.

Bloom, P. (2007). Religion is natural. Developmental Science, 10(1), 147-151

Boyer, P. (1993). The Naturalness of Religious Ideas. A Cognitive Theory of Religion. Berkeley: University of California Press.

Boyer, P. (2001). Religion Explained: the evolutionary origins of religious thought. New York: Basic Books.

Boyer, P. (2003). Religious Thought and Behavior as By-Products of Brain Function. Trends in Cognitive Sciences, 7(3), 119-124.

Boyer P (2013) Explaining religious concepts. Lévi-Strauss the brilliant and problematic ancestor. In D. Xygalatas, \& L. McCorkle (Eds), Mental Culture, Classical Social Theory and the Cognitive Science of Religion (pp. 164-175). Durham, UK: Acumen.

Boyer, P. \& Barrett, H. C. (2005). Domain specificity and intuitive ontology. In D. M. Buss (Ed.), The handbook of evolutionary psychology (pp. 96-118). Hoboken, NJ: John Wiley \& Sons Inc.

Boyer, P. \& Bergstrom, B. (2008). Evolutionary Perspectives on Religion. Annual Review of Anthropology, 37, 111-130.

Carrol, J. (2004) Literary Darwinism: Evolution, Human Nature, and Literature. London: Routledge.

Cohen, E. (2007). The mind possessed: The cognition of spirit possession in an Afro-Brazilian religious tradition. Oxford: Oxford University Press.

Davies, S. (2013). The Artful Species: Aesthetic, Art and Evolution. Oxford: Oxford University Press.

Durkheim, E. (2002). A vallási élet elemi formái: A totemisztikus rendszer Ausztráliában. (Ford. Vargyas Zoltán.) Budapest: L’Harmattan,

Guthrie, S. E. (1993). Faces in the Clouds: A New Theory of Religion. Oxford: Oxford University Press.

Hirschfeld, L. \& Gelman, S., Eds (1994). Mapping the Mind: Domain Specificity in Cognition and Culture. Cambridge: Cambridge University Press.

Hornbeck, R. G., \& Barrett, J. L. (2017). Introduction: Homo Religiosus and the Dragon In R. G. Hornbeck, J. L. Barrett, \& E. Kang, (Eds). Religious Cognition in China. „Homo Religiosus” and the Dragon (pp. 1-14). New York, NY: Springer.

Johnson, D. \& Bering, J. (2006). Hand of God, mind of man: Punishment and cognition in the evolution of cooperation. Evolutionary Psychology, 4, 219-233.

Kahneman, D. (2012). Gyors és lassú gondolkodás. Budapest: HVG.

Kelemen, D. (2004). Are children 'intuitive theists'? Reasoning about purpose and design in nature. Psychological Science, 15(5), 295-301.

Knight, N., Sousa, P., Barrett, J. L., \& Atran, S. (2004). Children's attributions of beliefs to humans and God: Cross-cultural evidence. Cognitive Science, 28(1), 117-126.

Krebs, D. L. (2011). The Origins of Morality: An Evolutionary Account. New York: Oxford University Press.

Lawson, E. T. (2001) Toward a Cognitive Science of Religion. Numen, 47(3), 338-349.

Lawson, E. T., \& McCauley, R. N. (1990). Rethinking Religion: Connecting cognition and culture. Cambridge: Cambridge University Press.

McCauley, R. N. (2011). Why religion is natural and science is not. New York: Oxford University Press.

McCauley, R. N. (2017). Twenty-Five Years In: Landmark Empirical Findings in the Cognitive Science of Religion. In L. H. Martin, D. Wiebe (Eds), Religion Explained?: The Cognitive Science of Religion after Twenty-five Years (pp. 24-45). London, New York: Bloomsbury. 
McClain-Jacobson, C., Rosenfeld, B., Kosinski, A., Pessin, H., Cimino, J. E., \& Breitbart, W. (2004). Belief in an afterlife, spiritual well-being, and end-of-life despair in patients with advanced cancer. General Hospital Psychiatry, 26(6), 484-486.

McCorkle, W. W., \& Xygalatas, D. (2013). Social Minds, Mental Cultures: Weaving Together Cognition and Culture in the Study of Religion. In D. Xygalatas, W. McCorkle (Eds), Mental Culture: Classical Social theory and the Cognitive Science of Religion (pp. 1-10). London: Acumen.

McCutcheon, R. T. (1997). Manufacturing Religion: The Discourse on Sui Generis Religion and the Politics of Nostalgia. Oxford: Oxford University Press.

McNamara, P. 2009. The Neuroscience of Religious Experience. Cambridge: Cambridge University Press.

Newberg, A. 2007. Born to Believe: God, Science and the Origin of Ordinary and Extraordinary Beliefs. New York: Free Press.

Norenzayan, A., Atran, S., Faulkner; J., \& M. Schaller, M. (2006). Memory and mystery: The cultural selection of minimally counterintuitive narratives. Cognitive Science, 3, 531-553.

Norenzayan, A. (2013). Big gods: How religion transformed cooperation and conflict. Princeton, NJ: Princeton University Press.

Pinker S. 2002. Hogyan múködik az elme. Budapest: Osiris.

Pléh Cs. (2013). A megismeréstudomány alapjai. Az embertôl a gépig és vissza. Budapest: Typotex.

Pyysiäinen, I. (2009). Supernatural agents: Why We Believe in Souls, Gods, and Buddhas. Oxford: Oxford University Press.

Pyysiäinen, I. (2012). Cognitive Science of Religion: State-of-the Art. Journal for the Cognitive Science of Religion, 1(1), 5-28.

Pyysiäinen, I., \& Hauser, M. (2010). The origins of religion: Evolved adaptation or by-product? Trends in Cognitive Sciences, 14(3), 104-109.

Richert, R. A. \& Barrett, J. L. (2005). Do You See What I See? Young Children's Assumptions About God's Perceptual Abilities. The International Journal for the Psychology of Religion, 15(4), 283-295.

Sands, R. R. (2009). The Science of God: Natural Origins of Religion in an Evolutionary Perspective. Journal for the Study of Religion, Nature and Culture 3(4), 437-457.

Slingerland, E., \& Bulbulia, J. (2011). Evolutionary cognitive science and the study of religion. Religion, 41(3), 1-23.

Slingerland, E., \& M. Collard, M. (2012). Creating Consilience: Toward a Second Wave. In E. Slingerland, \& M. Collard (Eds), Creating Consilience: Integrating the Sciences and the Humanities (pp. 3-40). Oxford-New York: Oxford University Press.

Sosis, R. (2009). The Adaptationist-Byproduct Debate on the Evolution of Religion: Five Misunderstandings of the Adaptationist Program. Journal of Cognition and Culture, 9, 315-332.

Sørensen, J. (2005). A cognitive theory of magic. Lanham, MA: Rowman \& Littlefield.

Sperber, D. (2001). A kultúra magyarázata. Naturalista megközelítés. Budapest: Osiris Kiadó.

Sperber, D., \& Mercier, H. (2015). A következtetés mint társas készség. Magyar Tudomány, 176 (2), 219-234.

Szabó L. (2016). A vallás kognitív és evolúciós magyarázatai. In Gyuris P., Meskó N. (szerk.), Evolúciós pszichológia mesterfokon. Pécs: Pro Pannonia.

Tooby, J. L., \& Cosmides L. (1992). The Psychological Foundations of Culture. In J. H. Barkow, L. Cosmides, \& J. Tooby (Eds), The Adapted Mind: Evolutionary Psychology and the Generation of Culture (pp. 19-136). Oxford-New York: Oxford University Press.

Tomasello, M. (2009) Why we Cooperate? Cambridge: MIT Press.

Tremlin, T. (2006). Minds and Gods: The Cognitive Foundations of Religion. Oxford: Oxford University Press. 
Wellman, H. M., Cross, D., \& Watson, J. (2001). Meta-analysis of theory-of-mind development: The truth about false belief. Child Development, 72(3), 655-684.

Visala, A. (2011). Naturalism, Theism and the Cognitive Study of Religion: Religion Explained? (Ashgate Science and Religion Series) Surrey: Ashgate.

Whitehouse, H. (2000). Arguments and Icons: Divergent modes of religiosity. Oxford: Oxford University Press.

Wilson, D. S., \& Green W. S. (2012). Evolutionary Religious Studies: A Beginner's Guide. In E. Slingerland, M. Collard (Eds), Creating Consilience: Integrating the Sciences and the Humanities (pp. 225-242). Oxford-New York: Oxford University Press.

Wilson, E. O. (1998/2003). Consilience: The Unity of Knowledge. New York: Alfred A. Knopf. (Minden egybecseng. Budapest: Typotex, 2003)

Xygalatas, D., \& McKay, R. (2013). Announcing the Journal for the Cognitive Science of Religion. Journal for the Cognitive Science of Religion 1(1), 1-4.

\title{
THE COGNITIVE THEORIES OF RELIGION: AN OVERVIEW
}

\author{
SZABÓ, LAJOS
}

The aim of the present study is to introduce and evaluate a relatively new field of scientific research which is known as the Cognitive Science of Religion (acronym as CSR). The scholars of CSR use theories and methods from cognitive science and cognitive psychology for understanding religions in a novel way. The following paper offers a comprehensive review of this new field of research, what is justified by three reasons. Firstly, in the latest years the CSR went through a period of significant development - and for now, it is on the treshold to becoming a new, autonomous scientific discipline. Second, on the other side of the coin, CSR and its results are hardly known in Hungary, so it will be useful to get a general summary for both the participants of Hungarian Cognitive Sciences, as well as of Science of Religions. Thirdly, it is important to highlight that the CSR succeed to apply a cognitive and naturalistic approach to religion, as a phenomenon what previously mainly belonged to the scope of the humanities and social sciences.

Keywords: cognitive science, science of religion, cognitive foundations of religion, agency, theory of mind 